\title{
Transposições e hibridizações empregadas em produtos midiáticos inovadores ${ }^{1}$
}



1

\section{David Santoro Junior}

Mestrando no Programa de Mestrado em Comunicação da Universidade Municipal de São CaetanodoSul-USCS.david@intelligencedm.com.br.

O livro Linguagens Na Mídia. Transposições e Hibridização como Procedimento de Inovação é o segundo volume da coleção Comunicação \& Inovação, editado pela linha de pesquisa Inovações na Linguagem e na Cultura Midiática, do Programa de PósGraduação em Comunicação da Universidade Municipal de São Caetano do Sul (USCS), organizado pelos professores Regina Rossetti e Herom Vargas, que também participam como autores.

Segundo os organizadores, estes estudos não têm o objetivo de concluir a função das novas linguagens ou de estabelecer conclusões sobre os temas estudados. O propósito da obra é provocar a reflexão, inspirar novas pesquisas e analisar as questões de hibridizações e transposições como procedimento de inovação aos produtos midiáticos.

A publicação é dividida em duas partes com quatro capítulos cada. Na primeira, Transposições de linguagens, os estudos refletem sobre alterações e inclusões, que não existiam na obra original, e que foram acrescentadas para recriá-las e adequá-las a uma linguagem diferente de sua origem, os capítulos enfocam as adequações das linguagens teatrais, o imaginário religioso do nordestino nas formas de narração para o cinema e televisão, a relação da ciência e da literatura para a construção de personagens e a relação entre arte e propaganda.

1 Rossetti, Regina \& VArgas. Herom (orgs). Linguagens na Mídia. Transposições e Hibridização como procedimentos de inovação. Porto Alegre: EDIPUCRS, 2013. (Coleção Comunicação \& Inovação; v.2). 
A segunda parte apresenta textos de autores que refletem as influências e transformações da música brasileira, dos meios de comunicação com o acréscimo das novas mídias digitais, os caminhos e possibilidades da TV digital e dos recursos humorísticos utilizado por Mauricio de Souza em seu trabalho.

O capítulo de Regina Rossetti e Flávio Diogo Silva abre a primeira parte do livro com um estudo sobre a obra $O$ Alto da Compadecida, escrita por Ariano Suassuna, e transformada para o cinema e televisão em formato de minissérie. As transformações da linguagem teatral foram analisadas, e apontadas, o diretor Guel Arraes influenciou na concepção e inserção de alguns personagens como Rosinha, que não está na trama original, e faz par romântico com Chicó, e a exclusão de personagens como o Frade e o Sacristão. As imagens e os diálogos foram construídos com a cultura do nordestino, o Diabo possui chifres de bode, que é um animal comum na região e as transformações de suas feições quando está bravo ele se parece com um morcego, que é um animal de hábitos noturnos e vive na escuridão. Jesus é representado por um negro, que representa o sofrimento de um povo que foi escravizado no período da colonização e império. João Grilo é a criatividade do brasileiro que encontra saídas para lidar com as dificuldades. No julgamento, o Diabo é o promotor, que julga e sugere as penas, Nossa Senhora é a defensora pública, único recurso dos mais pobres, e Cristo é o juiz, que analisa e define as punições.

O segundo capítulo, de Renato Luiz Pucci Jr., aborda como a obra A Pedra do Reino, de Ariano Suassuna, inova a forma narrativa dos programas televisivos. A morte é uma jovem sedutora e quando chega a hora de encontrá-la não há como escapar. $\mathrm{O}$ período da trama é o governo de Getúlio Vargas, o fato de o personagem principal estar preso não prova a sua culpa, porque o regime perseguia e prendia as pessoas sem motivos, devido a sua característica autoritária. Na história há dois narradores, ambos são o mesmo personagem em diferentes momentos de sua vida. O clímax da narrativa é o julgamento de Quaderma, acusado da morte de seu tio. Nesse momento, o telespectador não tem certeza da culpa do personagem, e a narrativa não esclarece isso, ela dá pistas, indica os prováveis culpados, mas deixa a conclusão para o telespectador. Por ser inovadora, a série não teve sucesso de audiência, porque a narrativa adotada para a série provocava no telespectador a interação por meio de pistas e mensagens, que necessitavam de atenção ao programa para serem compreendidas. Talvez este seja o motivo da baixa audiência, pois se o telespectador não presta atenção, ele perde o referencial da história e não entende a mensagem.

O terceiro capítulo de Carlos Gerbase reflete sobre a contribuição da ciência para a caracterização de personagens para narrativas literárias, a argumentação inicia-se com a citação da ligação de telefone de Spilberg para uma bióloga, para consultá-la sobre a 
construção do personagem E.T., e ela responde que a ciência e as artes são distintas e o cineasta deveria se preocupar com a história somente. A ciência pode contribuir para a criação literária e cinematográfica, pois ela fornece informações que darão mais veracidade à construção dos personagens. A tecnologia e o conhecimento contribuem para a evolução do homem e, no caso das artes, aprimora as características visuais. A narrativa desenvolve-se com o ponto de vista da filosofia, que como Aristóteles, criticava a inserção de um personagem divino para resolver os problemas da trama. Conhecimento biológico sobre espécies animais auxiliam para o desenvolvimento dos personagens, tornando-os mais verdadeiros. Conhecimentos psicológicos podem explicar os motivos que levam um homem maduro a escolher uma jovem mulher, porque ela representa a vida e a fertilidade, por outro lado, também explica a mulher madura escolher o jovem para dar "o troco" e o homem maduro que lhe oferece segurança.

O quarto capítulo de João Batista F. Cardoso e Roberta Esteves Fernandes, último da primeira parte, descreve a relação entre arte e propaganda e como as atividades influenciam-se mutuamente, o fato se deve à publicidade ser uma atividade que no passado acolheu artistas e escritores, que profissionalmente tornaram-se redatores e diretores de arte. A POP Art. é apontada como a vertente que mais aproximou-se da propaganda, porque Andy Warhrol trabalhou em agências como ilustrador e levou para a sua arte marcas conhecidas. René Magritti foi artista e publicitário e produziu conceitos artísticos que inicialmente foram usados na propaganda. O Dadaísmo é apontado como uma vertente artística na qual as apropriações e interferências foram adotadas na arte e propaganda. As campanhas desenvolvidas para o MASP, que foram analisadas, utilizaram parte do acervo do museu para compor a mensagem publicitária. As obras foram utilizadas, com inserção de textos, modificações nas obras e construção de sentido da mensagem. O uso é classificado como incorporação que pode ser total, ou fragmentada com interferências, e como imitação total ou fragmentada.

Herom Vargas inicia a segunda parte da obra com um estudo sobre a hibridização na MPB, que é estudada com o tropicalismo e o pós-tropicalismo, que foi um movimento que implantou instrumentos elétricos como a guitarra e o baixo, que eram usados no rock. O tropicalismo reflete o artista, o compositor e suas influências que vão além da sua cultura e gosto musical.

A luta política que ocorria no país no final dos anos 1960 situava, resumidamente, artistas e intelectuais entre duas claras posições: ou se colocavam em favor dos governos militares, ou se alinhavam às esquerdas e seus discursos engajados de salvação. Para um grupo de jovens compositores, alguns deles vindos da Bahia, pactuar com a ditadura não lhes parecia a melhor 
saída, tampouco se interessavam em vincular-se às esquerdas e reproduzir o nacionalismo das canções de protesto divulgadas pelos festivais de TV de grande audiência e mobilização (p.108).

Após o AI5, a perseguição à expressão artística intensificou-se, o artifício utilizado pelos compositores foram as performances, como a dos Secos e Molhados, ou então a criação sonora que remetia ao estado psicológico da época. As composições deixaram de ser um manifesto explícito, que era caracterizado por letras contestadoras e passou a ser gestual e simbólica. Como os modernistas, os tropicalistas romperam com o paradigma de que a MPB deveria recorrer à velha cartilha e usar os instrumentos tradicionais que a caracterizavam. Assim como o psicodelismo mudou o rock, a tropicália mudou a MPB com influências diversas, que aproximaram os brasileiros do movimento hippie, como os Novos Baianos que viveram em uma comunidade agrícola no Rio de Janeiro. No pós-tropicalismo, Milton Nascimento misturou o rock com a canção rural, e Tom Zé, com o álbum Todos os Olhos, escandalizou com a polêmica capa do seu disco com uma imagem de duplo sentido.

O sexto capítulo, de Laan Mendes de Barros, avalia a relação criador e receptor. Os meios digitais são híbridos por natureza porque oferecem informações e interatividade em um meio, ao contrário dos tradicionais, no qual a comunicação possui uma única via. Os meios digitais complementam e assumem o papel e o espaço dos veículos tradicionais, a comunicação deve ser repensada porque o comportamento do público mudou. As culturas convergem muito antes da cultura digital, a convivência entre culturas distintas, como índios, negros e colonizadores europeus resultaram em uma nova cultura com identidade própria que possui características de sua origem. Nos meios digitais o híbrido é natural, ferramentas como o Instagram, o Twitter e o Facebook unificam-se, e também há portais em que o cadastro para acesso restrito é feito com login e senha de uma mídia digital existente.

O sétimo capítulo, de Ana Silvia Lopes Davi Médola, discute as possibilidades da TV Digital e tem como objeto de estudo a animação Animeco, produzida pela TV da UNESP. No Brasil, a TV Digital é explorada por sua qualidade de imagem e sonora, o governo esforça-se para que o seu desenvolvimento seja pela interatividade, que é similar aos sistemas de computadores, em que o espectador pode interagir. O caminho desejado pelo governo poderia prejudicar comercialmente as emissoras porque a geração de conteúdo e controle sobre a divulgação são as fontes rentáveis para as emissoras, a TV por demanda é possível com os sistemas digitais, com este sistema o receptor teria acesso a um conteúdo de sua escolha, o que tornaria dispensável a programação tradicional. Animeco é um produto da TV Unesp, híbrido por ser um desenho animado no qual o

$200 \frac{\text { Comunicação \& Inovação, PPGCOM/USCS }}{\text { v. 15, n. } 29 \text { (197-201) jul-dez } 2014}$ 
telespectador interage utilizando o controle remoto da TV ou com seus dispositivos móveis, mas a história prossegue sua narrativa com ou sem interação.

O oitavo capítulo, de Roberto Elísio dos Santos, contextualiza as origens do humor, que remonta a antiga Grécia com Aristóteles, que associava a comédia ao feio e posicionava o gênero abaixo do drama, da epopeia e da tragédia, por ser a imitação dos homens inferiores. A definição mais atual classifica o humor como uma narrativa, que determina por questões culturais a história e geram o riso. $\mathrm{O}$ estudo tem a obra de Maurício de Souza como objeto de estudo, os recursos utilizados por ele são exemplificados como: textual com expressões de duplo sentido, a utilização de imagens sequenciais no qual o enquadramento omite o real significado e quando a imagem é desenhada a surpresa resulta no riso.

Assim, o Livro Linguagens na mídia reúne diversos pontos de vistas sobre os assuntos de transposições e hibridizações e comprova que os meios de inovação na cultura são processos experimentais e ousados que são utilizados para renovar as maneiras habituais de comunicação. A reunião dos estudos apresentados no livro são exemplos de produtos midiáticos como a Televisão, o cinema, a TV Digital e os quadrinhos, e também abre a discussão das novas possibilidades oferecidas pelos meios digitais. $\mathrm{O}$ tema de maior relevância para o momento é discutido nos sexto e sétimo capítulos, porque tratam das oportunidades que os meios digitais oferecem e da relação entre criador e receptor. A discussão sobre a TV Digital vai além do exemplo desenvolvido pela TV UNESP e aborda o conceito em que esta tecnologia pode ser utilizada e o conflito entre o ideal para o telespectador e o que pode ser viável comercialmente para as emissoras devido ao formato atual, no qual as emissoras controlam o que pode e quando deve ser exibido. 